\title{
Covid-19: \\ Upaya Preventif dan Kuratif ala Ibu Hamil
}

\author{
Astry Ayu Praharsini \\ Universitas Hasanuddin \\ astryayu54@gmail.com
}

\begin{abstract}
In 2020 all countries in the world are busy with a pandemic caused by the Covid-19 Virus. Indonesia is one of the countries whose citizens have been infected with Covid19 since March 2020 and its spread is fast. Symptoms of being infected with Covid-19 are cough, fever, shortness of breath, anosmia and muscle aches, but in some cases, a person who is exposed to Covid-19 does not even show symptoms at all. Covid-19 can attack various ages ranging from children to the elderly, gender, including pregnant women. Pregnant women are stated to be very vulnerable to contracting Covid-19 with various other diseases, the fear of fetal growth and development cannot be separated from the mother's worries during the Covid-19 pandemic. This article deals with how pregnant women prevent being infected with Covid-19 and how they treat themselves when infected with Covid-19.
\end{abstract}

This research was conducted in the city of Makassar. The informants involved in this study consisted of 10 pregnant women who are varied on the basis of age (between 19 and 26 years, gestational age (between 12 and 32 weeks) and occupation (seven housewives, a celebgram, a pharmacist, and a nurse). Data was collected usingthe combination of interview and observation.

In this study, it was found that the positive impacts of Covid-19 pandemic for pregnant women that their togetherness with members of the family becomes more intensive because they spend more time at home, they are more concerned about personal and family hygiene, they are more physically and mentally healthy, and they become more creative in using their free time. While the negative impact of Covid-19 for pregnant women is that they experience anxiety during the Covid-19 period. However, those who have a better understanding of Covid-19 tend to be positive in dealing with it. Although the efforts made by pregnant women in relation to prevention and treatment are similar but not the same, in preventive efforts, pregnant women are more likely to combine physical activity and various intakes related to efforts to maintain immunity. Meanwhile, in curative efforts, pregnant women limit the duration of physical activity and are more routine in carrying out healing efforts. The difference in nutritional intake also lies in vitamin supplements. In preventive efforts the consumption of supplements is not so ignored and focused on the food consumed, while in a curative effort, they tend to balance food intake and supplements to maintain immunity and accelerate recovery. It is argued in this article that despite the fact pregnant women are vulnerable group, they do not have their own specific treatment either to prevent or to treat them in relation to Covid-19.

Keywords: Covid-19, pregnant women, impact, preventive, and curative.

\section{Pendahuluan}

Pada tahun 2020 seluruh negara di dunia disibukkan dengan adanya pandemi yang disebabkan oleh Virus Covid-19. Virus
Covid-19 pertama kali ditemukan pada akhir tahun 2019 di Kota Wuhan, Cina dengan 180 kasus. Adapun gejala jika seseorang terinfeksi Covid-19 yakni batuk, 
demam, sesak napas, pegal otot bahkan untuk beberapa kasus tidak memiliki gejala sama sekali. Indonesia merupakan salah satu Negara yang warganya terinfeksi Covid-19 dimulai pada bulan Maret 2020 dan penyebarannya terjadi dengan cepat. Hingga saat ini menurut data terbaru 2021 dari website resmi Covid-19 Indonesia tercatat 4,258,752 kasus terkonfirmasi terinfeksi covid-19 dan 143,923 kasus meninggal dunia. ${ }^{1}$

Angka kematian yang semakin meningkat membuat penyakit tersebut mendapat perhatian yang serius dari berbagai kalangan. Zaigham dan Andersson (dalam Chahya dkk. 2020:77) mengemukakan bahwa Covid-19 menyerang semua usia, termasuk kelompok rentan, salah satunya ibu hamil. Pada kondisi hamil terjadi perubahan fisiologis tubuh dan imunitas ibu yang menyebabkan peningkatan kerentanan terhadap infeksi penyakit. Apalagi di masa pandemi terjadi pembatasan aktivitas, termasuk pembatasan layanan kesehatan pada ibu hamil (Setyawan dkk. 2019:54). ini menyebabkan turunnya persentase kunjungan ibu hamil karena mereka takut akan tertular Covid-19. Ini karena Ibu hamil yang terifeksi Covid-19 memiliki risiko tinggi, terutama risiko kelahiran premature (Pradana dan Casman dalam Herlina dkk. 2021:45). Jika melahirkan di rumah sakit/fasilitas kesehatan lainnya, ibu hamil perlu mendapat perhatian khusus berkaitan dengan ruang perawatan intensif, ventilasi invasif dan ruang perawatan neonatal intensif (Madjunkov dkk. 2020 dalam Kostania dkk. 2021:113).

Zaigham dkk. (dalam Damayanti dan Riafisari 2020:708) mengemukakan bahwa manifestasi infeksi Covid-19 untuk ibu hamil paling sering dilaporkan adalah gagal napas dan sepsis berat, mengingat kecenderungan disregulasi respon imun, dan perubahan microbiome pernapasan setelah virus menyerang dan mengakibatkan radang paru-paru. Dari tanda dan gejala klinis, ibu hamil dengan Covid-19 biasanya mengalami demam saat masuk rumah sakit (68\%), batuk kering yang persisten (34\%), malaise (13\%), dispnea (12\%), dan diare (6\%). (Pradip dkk. 2020). Ini sebenarnya mirip dengan pasien tidak hamil. Fitur dominan Covid-19 pada pasien hamil adalah demam, batuk, dispnea, dan limfopenia. Beberapa komplikasi pada bayi baru lahir dan ibu hamil dengan Covid-19 antara lain: keguguran (2\%), intrauterine growth restriction (IUGR; 10\%), dan kelahiran prematur (39\%). Gejala demam yang dialami berkisar pada suhu 38.1- 39.0 derajat celcius (Damayanti dan Riafisari 2020:708).

Untuk pengobatan ibu hamil positif sejauh ini belum ada protokol konsensual yang resmi. Oleh karena itu, perawatan dan tatalaksana kesehatan dikondisikan dengan tujuan utama perawatan yang didasarkan pada mengisolasi ibu hamil, mengklasifikasikannya menurut resiko dan kebutuhan yang ditentukan oleh kondisi klinis; merekomendasikan tidur dan istirahat yang tepat, memromosikan nutrisi yang tepat, memberikan dukungan oksigen tambahan (jika diperlukan) dan memantau asupan cairan dan elektrolit. Selain itu, tanda-tanda vital dan tingkat saturasi oksigen harus dipantau secara ketat, serta frekuensi detak jantung janin untuk mengamati perkembangan kehamilan, merencanakan persalinan individual, dan memiliki tim multiprofesional untuk memberikan perawatan (Wu dkk. dalam Rialdi dan Agung 2021:6).

Upaya kesehatan diwujudkan
dalam bentuk kegiatan pencegahan
penyakit (preventif), peningkatan
kesehatan (promotif), pengobatan penyakit
(kuratif) dan pemulihan kesehatan
(rehabilitasi). Uupaya preventif dan kuratif

${ }^{1}$ https://covid19.go.id, diakses tanggal 11

Desember 2021 
menjadi satu kesatuan dalam menangani Covid-19 terutama pada ibu hamil. Upaya preventif dan kuratif pada ibu hamil menjadi penting dikarenakan ibu hamil termasuk kedalam masyarakat yang rentan akan Covid-19.

Literatur yang ada umumnya berkaitan dengan edukasi pencegahan infeksi Covid-19 selama masa kehamilan (Juneris dkk. 2020; Ronni dkk. 2020; Erlinawati 2020). Juneris dkk., 2020) yang memfokuskan studinya pada peningkatan pemahaman kesehatan pada ibu hamil dalam upaya pencegahan Covid-19, mengungkapkan bahwa penelitian yang dilakukan dengan teknik penyuluhan di Balai Pengobatan Swasta Mariana menunjukkan adanya peningkatan pengetahuan dan pemahaman ibu hamil dalam upaya pencegahan Covid-19, yakni $50 \%$ lebih baik setelah dilakukan kegiatan penyuluhan tersebut. Selain peningkatan pengetahuan dan pemahaman, kecemasan para ibu hamil pun mengalami penurunan sebanyak $12 \%(67.6 \%)$ pasca penyuluhan. Studi Ronni dkk. (2020) yang menitikberatkan penelitiannya pada pemahaman ibu hamil tentang upaya pencegahan infeksi Covid-19 selama masa kehamilan mengindikasikan bahwa mayoritas ibu hamil yang berkunjung ke Balai Pengobatan Mariana kurang memiliki pengetahuan tentang upaya pencegahan infeksi Covid-19. Temuan Erlinawati dkk. (2020) dalam studinya tentang pendidikan kesehatan pada ibu hamil dalam pencegahan penularan Covid-19 di Puskesmas Kuok menunjukkan bahwa sebelum diberikan pendidikan kesehatan, mayoritas (80\%) pengetahuan ibu hamil di Puskesmas Kuok relatif masih rendah. Namun, setelah diberikan penyuluhan terjadi peningkatan pengetahuan yang sangat signifikan hingga $100 \%$. Jika literatur yang ada lebih terfokus pada upaya pencegahan dalam bentuk edukasi, maka studi literatur tentang upaya pencegahan Covid-19 pada ibu hamil yang dilakukan oleh Eliyun dan Rahayuningsih (2021) menunjukkan bahwa upaya tersebut masih sangat umum, yakni dengan penerapan protokol kesehatan dasar (memakai masker, mencuci tangan, menjaga jarak), berolah raga, pola makan yang seimbang dan bergizi. Sementara literatur yang mengkaji tentang upaya pengobatan yang dilakukan oleh ibu hamil ketika mereka terinfeksi Covid-19 jikapun ada, masih sangat terbatas. Studi literatur yang dilakukan oleh Rohmah dan Nurdianto (2020), misalnya, menunjukkan bahwa umumnya ibu hamil yang terinfeksi Covid-19 tergolong kasus ringan, jika terjadi transmisi vertikal juga rendah, minimnya kasus spontaneous abortion, kelahiran bayi prematur, kematian bayi, serta gangguan perkembangan. Ibu hamil yang terinfeksi Covid-19 dan menyusui bayinya juga masih relatif aman. Artikel ini mengisi gap tersebut.

Artikel ini berfokus pada upaya yang dilakukan oleh ibu hamil baik sebagai upaya preventif, maupun dalam kaitan dengan upaya kuratif jika ibu hamil terinfeksi Covid-19. Pembahasan dalam artikel ini dibagi menjadi tiga bagian. Bagian pertama akan mengeksplorasi tentang dampak pandemi Covid-19 yang dirasakan oleh ibu hamil. Bagian kedua akan mendiskusikan tentang upaya preventif ibu hamil untuk pencegahan Covid-19. Bagian ketiga akan membahas tentang upaya kuratif yang dilakukan jika ibu hamil terinfeksi Covid-19.

\section{Metode Penelitian}

Penelitian yang berlangsung antara bulan September dan November 2021 ini dilakukan di kota Makassar, Sulawesi Selatan dengan pertimbangan kota Makassar merupakan salah satu kota urutan ketiga dengan angka Covid-19 
tertinggi di Indonesia pada tahun $2020,{ }^{2}$ dan pernah melaksanakan PSBB sebanyak dua kali.

Informan dalam penelitian ini adalah ibu hamil, baik yang terinfeksi Covid-19 maupun yang tidak. Penentuan informan dilakukan secara purposive sampling. Informan yang terlibat dalam penelitian ini adalah ibu hamil yang berusia antara 19 tahun dan 26 tahun, dengan usia kehamilan antara 12 dan 32 minggu.
Mereka berjumlah sepuluh orang, yang terdiri atas tujuh orang ibu rumah tangga (IRT) dan tiga orang yang masing-masing memiliki pekerjaan berbeda, yakni selebgram, apoteker, dan perawat. Dari sepuluh ibu hami, tiga bergejala, tapi tidak melakukan tes Covid-19; dua orang positif terinfeksi Covid-19, dan lima orang tidak terinfeksi Covid-19, sebagaimana dijabarkan pada Tabel 1 berikut ini.

\begin{tabular}{|c|c|c|c|c|c|}
\hline \multicolumn{6}{|c|}{ Tabel 1. Informan Penelitian } \\
\hline No. & Nama & $\begin{array}{l}\text { Umur } \\
\text { (Tahun) }\end{array}$ & $\begin{array}{c}\text { Usia } \\
\text { Kandungan } \\
\text { (Minggu) }\end{array}$ & Pekerjaan & Status \\
\hline 1. & Hilda Febrianti & 19 & 12 & Selebgram & $\begin{array}{l}\text { Tidak Terpapar } \\
\text { Covid-19 }\end{array}$ \\
\hline 2. & Dwi Elvira Fadillah & 21 & 20 & IRT & $\begin{array}{l}\text { Bergejala Covid-19 } \\
\text { (tidak test Covid-19) }\end{array}$ \\
\hline 3. & Rizky Auliya & 23 & 12 & IRT & $\begin{array}{l}\text { Tidak Terpapar } \\
\text { Covid-19 }\end{array}$ \\
\hline 4. & Warda Amin & 24 & 28 & IRT & $\begin{array}{l}\text { Bergejala Covid-19 } \\
\text { (negatif Covid-19) }\end{array}$ \\
\hline 5. & Mangkawani D. R. & 24 & 16 & IRT & $\begin{array}{l}\text { Tidak Terpapar } \\
\text { Covid-19 }\end{array}$ \\
\hline 6. & Andi Risty Anita & 24 & 16 & IRT & $\begin{array}{l}\text { Tidak Terpapar } \\
\text { Covid-19 }\end{array}$ \\
\hline 7. & Ghina Ramadhani & 24 & 24 & Apoteker & Positif Covid-19 \\
\hline 8. & Indah Permata Sari & 24 & 12 & Perawat & Positif Covid-19 \\
\hline 9. & Wiji Teguh Rahayu & 25 & 28 & IRT & $\begin{array}{l}\text { Bergejala Covid-19 } \\
\text { (tidak test Covid-19) }\end{array}$ \\
\hline 10. & Erna Sari & 26 & 32 & IRT & $\begin{array}{l}\text { Tidak Terpapar } \\
\text { Covid-19 }\end{array}$ \\
\hline
\end{tabular}

Teknik pengumpulan data yang digunakan dalam penelitian ini adalah pengamatan (observation) dan wawancara mendalam (in-depth interview) dengan menggunakan pedoman wawancara. Observasi dilakukan untuk melihat aktivitas yang dilakukan ibu hamil selama pandemi Covid-19 dengan mengamati kegiatan ibu

${ }^{2}$ https://news.detik.com/berita/d-5076725/sulselurutan-3-insiden-covid-19-tertinggi-ini-laju- hamil, seperti senam hamil dan berbagai kegiatan rumah tangga yang dilakukan mengingat mereka kebanyakan menghabiskan waktu di rumah. Wawancara mendalam dilakukan untuk mengetahui upaya penanganan Covid-19 yang dilakukan oleh ibu hamil dalam menjaga kesehatan diri dan janin. Adapun

tambahan-dalam-sepekan, diakses tanggal 17 Desember 2021. 
proses wawancara dilakukan secara tatap muka (face to face). Untuk meyakinkan informan jika melakukan wawancara secara langsung, maka saya menunjukkan hasil rapid test antigen dan kartu vaksin, baik vaksin pertama maupun kedua. Bagi informan yang tidak berkenan untuk melakukan wawancara secara tatap muka, maka wawancara dilakukan secara online melalui aplikasi Whatsapp, via chatting, voice note, room chat dan video call, tergantung dari kesepakatan bersama.

Analisis data dalam penelitian ini dilakukan dengan mengumpulkan datadata selama di lapangan, yang berupa transkip wawancara dan catatan observasi. Dari hasil penelusuran data ditemukan tema-tema yang meliputi dampak pandemi Covid-19 terhadap ibu hamil, aktivitas ibu hamil di masa pandemi, dan asupan nutrisi yang dikonsumsi ibu hamil demi menjaga imunitas tubuh, upaya yanh dilakukan jika terinfeksi Covid-19. Ini kemudian dilanjutkan dengan mengklasifikasikan data berdasarkan tema, lalu menampilkan data secara sistematis dan terorganisir sehingga mudah dipahami. Ini dilanjutkan dengan memaknai temuan-temuan, sebelum akhirnya menarik kesimpulan.

Dalam penelitian ini, informan direkrut berdasarkan informasi orangorang sekitar yang memiliki kenalan ataupun kerabat mengenai ibu hamil. Kesediaan informan diminta melalui personal chat pada aplikasi Whatsapp yang nomornya diperoleh dari temannya atas izin yang bersangkutan. Jika informan bersedia untuk dihubungi, maka ini dilanjutkan dengan menghubungi yang bersangkutan. Pertama-tama saya menjelaskan identitas saya, maksud dan tujuan penelitian, serta manfaat penelitian. Jika mereka setuju untuk berpartisipasi dalam penelitian ini, maka mereka akan dimintai kesediaan untuk diwawancarai dan direkam wawancaranya. Semua informan menyatakan persetujuannya untuk digunakan nama asli mereka.

\section{Dampak Pandemi Covid-19 Terhadap Ibu Hamil}

Salah satu yang terdampak akan pandemi Covid-19 adalah ibu hamil. Ibu hamil adalah kelompok yang rentan terhadap patogen penyebab penyakit pernafasan dan pneumonia. Ini karena dalam keadaan hamil, tubuh berada pada keadaan imunosupresif dan mengalami perubahan fisiologis kehamilan (seperti peningkatan diafragma, peningkatan konsumsi oksigen, dan edema mukosa saluran pernafasan yang juga dapat membuat rentan terhadap hipoksia). Kerentanan ini semakin meningkat jika imunitas ibu hamil menurun (Herbawani dkk. 2020:82). Jika dipandang dari sisi sosial, maka temuan penelitian ini menunjukkan bahwa dampak pandemi Covid-19 terhadap ibu hamil tidak hanya dilihat dari sisi negatif sebagaimana klaim banyak orang, tapi juga ada dampak positif yang ditimbulkannya, sebagaimana yang akan didiskusikan berikut ini.

\section{Dampak Negatif}

Salah satu dampak negatif dari pandemi Covid-19 terhadap ibu hamil adalah kesehatan mental. Menurut Arisanti (2021), ibu hamil merupakan kelompok dengan faktor risiko tinggi yang rentan terhadap suatu masalah atau gangguan kesehatan, termasuk kesehatan mental. Ibu hamil mengalami beragam rasa takut, seperti ketakutan untuk mengakses pusat-pusat layanan kesehatan, ketakutan akan risiko terpapar virus, serta ketakutan tidak adanya dukungan emosional dari keluarga.

Temuan kajian literatur yang dilakukan oleh Hinonaung dkk. (2021) mengindikasikan bahwa ibu hamil yang memahami tentang Covid-19 cenderung bersikap positif dalam menghadapi pandemi Covid-19. Namun demikian, mereka juga mengalami kecemasan terkait persalinan dengan operasi caesar, demam, 
dan batuk. Dalam konteks penelitian ini, ketakutan yang dialami oleh ibu hamil cukup bervariasi, mulai dari ketakutan karena merasa terisolir, ketakutan karena pandemi Covid-19 berdampak pada ekonomi, ketakutan mengakses layanan kesehatan untuk pemeriksaan kandungan, ketakutan akan kesehatan janin, ketakutan untuk melakukan tes Covid-19 karena takut hasilnya positif, dan ketakutan terinfeksi Covid-19.

Sejak pandemi Covid-19, Mangkawani (24 tahun) yang tinggal di perantauan (ia berasal dari salah satu kabupaten di Sulawesi Selatan yang merantau dan tinggal di Kota Makassar) mengalami ketakutan yang beragam. Pertama, karena merasa terisolasi, sebagai perantau yang hanya tinggal berdua dengan suaminya dan tidak diperbolehkan mudik pada waktu libur ataupun lebaran; kedua, ketakutan karena usaha suaminya juga sedang menurun akibat pandemi Covid-19; ketiga, ketakutan mengakses layanan kesehatan untuk melakukan pemeriksaan rutin. Berbagai ketakutan ini membuat ia mengalami stres yang berkepanjangan. Ini kemudian membuatnya sering overthinking setiap malamnya dan waktu tidurnya pun terganggu, bahkan tidak jarang ia mengalami insomnia. Dalam mengatasinya, ia menghibur diri dengan menonton film. la juga meminum susu atau teh hangat yang dicampurkan dengan madu jika ia susah tidur. Ini membuatnya lebih tenang dan tidurnya pun menjadi lebih nyenyak.

Selama pandemi Covid-19, Andi (24 tahun) selalu diliputi rasa ketakutan dalam kaitan dengan kehamilannya. Ketakutan itu bervariasi, mulai dari ketakutan terinfeksi Covid-19, ketakutan akan kesehatan janinnya, ketakutan untuk memeriksa kandungan ke layanan kesehatan. Ini membuatnya stres menurunkan imun tubuhnya dan ini berpengaruh terhadap janin yang dikandungnya. la mengkonsumsi suplemen penambah daya tahan tubuh (Ester C, lihat Gambar 1) serta asupan yang mengandung asam folat, seperti susu khusus ibu hamil untuk menjaga kesehatan dan tumbuh kembang janin. Untuk mengatasi stresnya, ia belajar dari aplikasi Youtube, yakni dengan melakukan meditasi yang dapat membantu dalam mengelola emosi dan mengurangi rasa cemas serta stres. Selain meditasi, iapun mandi dengan air hangat yang memberikan efek menenangkan. la juga secara regular melakukan konsultasi secara online pada dokter kandungannya.

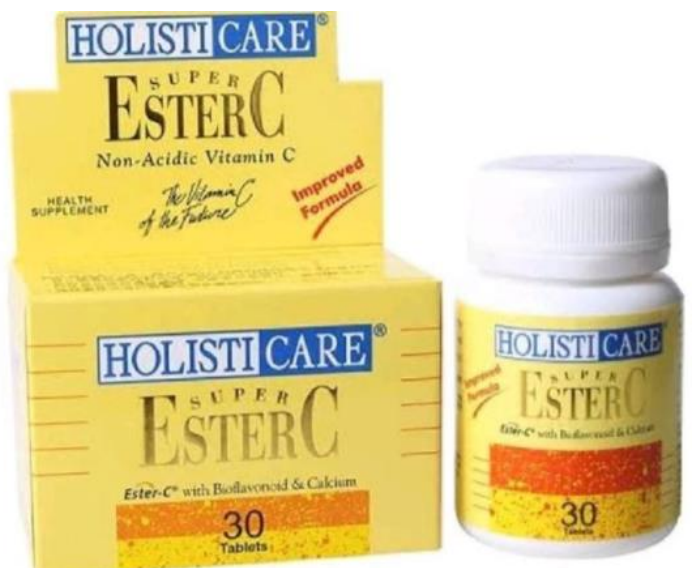

Gambar 1. Vitamin Holiticare Ester $C^{3}$

\footnotetext{
${ }^{3}$ https://ecs7.tokopedia.net/blog-tokopedia-com/uploads/2021/07/holisticare-ester-c.jpg, diakses tanggal 11 Desember 2021.
} 
Hal Serupa Terjadi Pada Dwi (21 tahun), ia merasakan ketakutan berlebihan ketika mengetahui dirinya bergejala Covid19, tapi tidak berani dalam melakukan tes Covid-19 dikarenakan takut jika hasilnya positif Covid-19. la mengaku sempat stres dan pikiran negatif mengenai dirinya beserta janin terus membayangi. Alhasil kondisi kesehatannya sempat menurun walau hanya beberapa hari saja. Selama kondisi kesehatannya menurun, ia mengonsumsi obat-obatan berupa antibiotik dan suplemen penambah darah. Indah (24 tahun), disaat mengandung ia terinfeksi Covid-19 dengan hasil tes positif Covid-19. la mengatakan kemungkinan besar ia terinfeksi dikarenakan pekerjaannya sebagai perawat, yang mengharuskannya berinteraksi secara langsung terhadap pasien dan orang banyak. Tidak dapat dipungkiri iapun memiliki ketakutan mengenai kesehatan dirinya beserta kesehatan dan keselamatan sang janin.

\section{Dampak Positif}

Jika selama ini kita sering mendengar atau membaca berita yang hanya mengekspos dampak negatif dari pandemi Covid-19, maka bagi ibu hamil pandemi Covid-19 juga memiliki dampak positifnya. Beberapa dampak positif yang dirasakan oleh ibu hamil selama masa pandemi Covid-19 adalah hubungan keluarga lebih erat dan harmonis, lebih peduli terhadap kebersihan diri dan keluarga, lebih menjaga kesehatan fisik dan mental, serta menjadi kreatif dalam memanfaatkan waktu luang.

Keluarga merupakan satuan unit terkecil dalam masyarakat yang bisa berupa keluarga inti (dari ayah, ibu, dan anak-anak yang belum menikah); single parents (ayah dan anak, ibu dan anak); atau keluarga luas (ayah, ibu, anak-anak, sepupu, tante/om, nenek/kakek, dll.). Di masa pandemi Covid-19, ada berbagai kebijakan pemerintah yang membatasi masyarakat masyarakat untuk keluar rumah, seperti work from home (WFH), pembatasan sosial berskala besar (PSBB), mengharuskan seluruh anggota keluarga untuk tetap berada di rumah dan lebih banyak melakukan kegiatan di dalam rumah dengan membatasi interaksi di luar. Hal ini membuat keeratan keluarga terjalin baik, romantis dan harmonis karena seringnya bertemu (Fauziah dan Afrizal 2021:974). Rizky (23 tahun) merasakan bagaimana di saat pandemi Covid-19 ia memiliki lebih banyak waktu bersama keluarga dan membangun hubungan emosional yang semakin erat. Hal tersebut justru jarang terjadi sebelum pandemi Covid-19 karena kesibukan masingmasing. Tapi sejak pandemi Covid-19, semua anggota keluarga lebih banyak menghabiskan waktu di rumah, jika pun ada yang terpaksa harus keluar rumah, biasanya tidak lama, sehingga waktu memang banyak dihabiskan di rumah bersama keluarga. Pernyataan serupa dikemukakan oleh Erna (26 tahun) bahwa eksistensi pandemi Covid-19 membuat hubungannya dengan keluarga sang suami semakin erat karena semenjak ia hamil, yang bertepatan dengan Covid-19, ia tinggal bersama keluarga sang suami.

Erna juga semakin memerhatikan kebersikan diri dan memerhatikan kesehatan keluarga dibandingkan sebelum pandemi Covid-19. la menjadi lebih peduli terhadap kebersihan tubuh dan pakaian (seperti mandi dua kali sehari, menggunakan hand sanitizer, mengganti dan mencuci pakaian jika telah digunakan keluar. la dan keluarganya juga mengonsumsi makanan yang diolah sendiri dengan bahan makanan yang dipilih sendiri, sehingga ia yakin dengan kebersihan makanan yang dikonsumsinya. Hal serupa dilakukan oleh Wiji (25 tahun) yang mengatakan bahwa selama ia hamil, ia memilih untuk memasak makanan yang akan ia konsumsi sendiri daripada membeli 
makanan di luar yang belum terjamin kebersihannya.

Dampak positif lainnya yang dialami oleh ibu hamil adalah di masa pandemi Covid-19 adalah dengan mengembangkan potensi yang dimilikinya yang selama ini tidak tereksplorasi di saat kejenuhan melanda, seperti membuat kue, menjahit, bahkan bercocok tanam (menanam bunga). Erna (26 tahun), misalnya, selama masa pandemi Covid-19 ia dapat mengeksplorasi keterampilan barunya, seperti belajar membuat kue dan menjahit yang awalnya hanya ia lakukan untuk mengatasi kebosanan karena berdiam diri dirumah. Kini ia telah cukup mahir dalam membuat kue dan menjahit, bahkan ia dapat membuat beberapa jenis kue, baik kue kering maupun kue basah. Untuk keterampilan menjahitnya, ia telah mampu membuat baju-baju bayi, meskipun ia masih harus banyak belajar.

Ghina (24 tahun), yang meskipun ia pernah terinfeksi Covid-19, ia menjadikan waktunya selama masa terisolasi di rumah, ia menikmati hobbi-nya menanam bunga. Ghina memiliki koleksi tanaman bunga yang beragam. Bagi Ghina, dengan menanan dan merawat bunga, ini dapat membuat pikirannya lebih segar dan tidak terbebani dengan dirinya yang positif Covid-19.

\section{Upaya Preventif Ibu Hamil}

Di awal pandemi Covid-19, pemerintah memberlakukan kebijakan Pembatasan Sosial Berskala Besar (PSBB), sebagaimana diatur dalam Peraturan Walikota No. 20 Tahun 2020 tentang Pembatasan Sosial Berskala Besar dalam Rangka Percepatan Penanganan Corona Virus Disease 2019 (Covid-19) yang ditetapkan pada tanggal 21 Maret 2020 yang pemberlakukannya dimulai pada minggu ketiga bulan April. Ini dilanjutkan dengam PSBB kedua berdasarkan Keputusan Walikota No. 1153/360/Tahun 2020 tentang Penetapan Perpanjangan
Pemberlakuan Pelaksanaan PSBB di Kota Makassar Provinsi Sulawesi Selatan yang diberlakukan di bulan Mei 2020. Apa saja aktivitas ibu hamil sebagai upaya preventif agar tidak tertular Covid-19? Temuan penelitian ini menunjukkan bahwa ibu hamil melakukan aktivitas fisik dan menjaga asupan nutrisi mereka di masa pandemi Covid-19.

\section{Aktivitas Fisik Ibu Hamil}

Dalam pencegahan penularan Covid-19, aktivitas yang dilakukan oleh ibu hamil terutama dengan mematuhi protokol kesehatan yang dicanangkan oleh pemerintah, sebagaimana tertuang dalam Keputusan Menteri Kesehatan (Kepmenkes) Republik Indonesia Nomor HK.01.07/MENKES/382/2020 Tentang Protokol Kesehatan Bagi Masyarakat di Tempat dan Fasilitas Umum Dalam Rangka Pencegahan Pengendalian Covid19. Jika merujuk pada Kepmenkes ini, maka salah satu bentuk perlindungan kesehatan individu adalah selain $3 \mathrm{M}$ (menggunakan masker, membersihkan tangan, dan menjaga jarak), juga meningkatkan daya tahan tubuh dengan menerapkan perilaku hidup bersih dan sehat (PHBS), seperti mengonsumsi gizi seimbang, aktivitas fisik minimal 30 menit dan istirahat yang cukup, serta menghindari faktor resiko penyakit.

Aktivitas fisik adalah gerakan anggota tubuh yang mengeluarkan tenaga untuk menjaga kesehatan fisik dan mental, mempertahankan kualitas hidup agar tetap sehat dan bugar (Fatmah dalam Indarwati dkk. 2019:10). Menurut Yanuari dkk. (dalam Indarwati dkk. 2019:09) ibu hamil yang sering beraktivitas fisik secara rutin akan lebih baik kebugaran tubuhnya, dibandingkan jika ia hanya duduk dan tidur sepanjang hari, apa lagi di masa pandemi Covid-19, dimana aktivitas fisik, seperti berolah raga, adalah salah satu cara untuk menjaga imunitas tubuh. 
Oleh karenanya, anjuran untuk aktif bergerak bagi ibu hamil penting untuk diperhatikan karena aktivitas fisik yang dilakukan selama ibu dalam keadaan hamil membuat ibu menyesuaikan tubuh dengan kondisi berat badan yang semakin bertambah, membantu mempermudah persalinan, menjaga kebugaran, terhindar dari komplikasi kehamilan dan stres berkurang (Arum dalam Ahmad dkk. 2020:346). Adapun aktivitas fisik yang dilakukan oleh ibu hamil selama masa kehamilan disaat pandemi Covid-19 yakni jalan pagi serta melakukan pekerjaan rumah tangga. Keduanya termasuk dalam kategori aktivitas fisik yang jika dilakukan secara rutin dapat membantu kebugaran tubuh dan dapat mencegah penyakit. Menurut Yuliarti (dalam Indah dan Rosmania 2017:16), ibu hamil akan merasakan kenyamanan dan kebugaran setelah melakukan olah ragi pagi (jalanjalan pagi), memiliki rasa percaya diri yang tinggi dan lebih bersemangat. Dalam menjaga kesehatan diri Rizky (23 tahun), misalnya, secara rutin melakukan aktivitas jalan pagi dan dilanjutkan dengan berjemur demi menjaga imunitas tubuh. Sebenarnya, menurut Tri Murti (dalam Anggraini dan Anjani 2021:45), vitamin D yang dapat diperoleh dari paparan sinar matahari, dapat juga diperoleh dari makanan seperti ikan salmon, telur, keju dan produk susu olahan, sehingga orang dapat mensubstitusi vitamin $D$ sesuai dengan kondisinya. Misalnya, jika seseorang tidak sempat berjemur, maka ia dapat mengonsumsi makanan yang fungsinya sepadan dengan vitamin $D$ dari sinar matahari, sehingga kebutuhan vitamin $\mathrm{D}$ tetap dapat terpenuhi.
Melakukan aktivitas berupa pekerjaan rumah tangga seperti mencuci, memasak ataupun membersihkan rumah adalah aktivitas yang dapat membuat seseorang bergerak aktif, termasuk bagi ibu hamil. Hilda (19 tahun) mengatakan ia lebih banyak menghabiskan waktunya untuk beraktivitas di dalam rumah dengan mengerjakan pekerjaan rumah dan berselancar di media sosial. Semua aktivitas luar yang biasa ia lakukan, seperti berbelanja kebutuhan pokok, kini dilakukan oleh suaminya. Ini tidak berarti bahwa Hilda tidak mau melakukannya, tapi ia takut untuk keluar rumah dan ia juga tidak diizinkan untuk itu. Hal serupa diungkapkan oleh Mangkawani (24 tahun) yang mengatakan bahwa selama pandemi Covid-19 ia hanya beraktivitas di dalam rumah saja (\#dirumahaja), yakni mengurus rumah tangga dan menikmati hobinya menonton film yang di masa sebelum pandemi sangat jarang terjadi karena ia sibuk. Ini kemudian menjadi aktivitas rutinnya selama pandemi Covid-19.

Aktivitas lainnya yang dilakukan oleh ibu hamil sebagai pengganti olahraga ialah naik turun tangga, seperti yang dilakukan oleh Indah (24 tahun menjelaskan) yang pernah terinfeksi Covid19. Dengan adanya sejumlah kasus orang yang telah sembuh dari Covid-19 dapat kembali terinfeksi, maka Indah tetap melakukan upaya-upaya preventif. la mengombinasikan antara senam hamil di rumah (untuk illustrasi lihat Gambar 2) dan naik turun tangga. Olehnya itu, ia memindahkan kamarnya dari lantai I ke lantai II, agar naik-turun tangga menjadi kegiatan rutinnya di rumah. Aktivitas naikturun tangga sangat membantu dalam mengelola pernafasannya. 


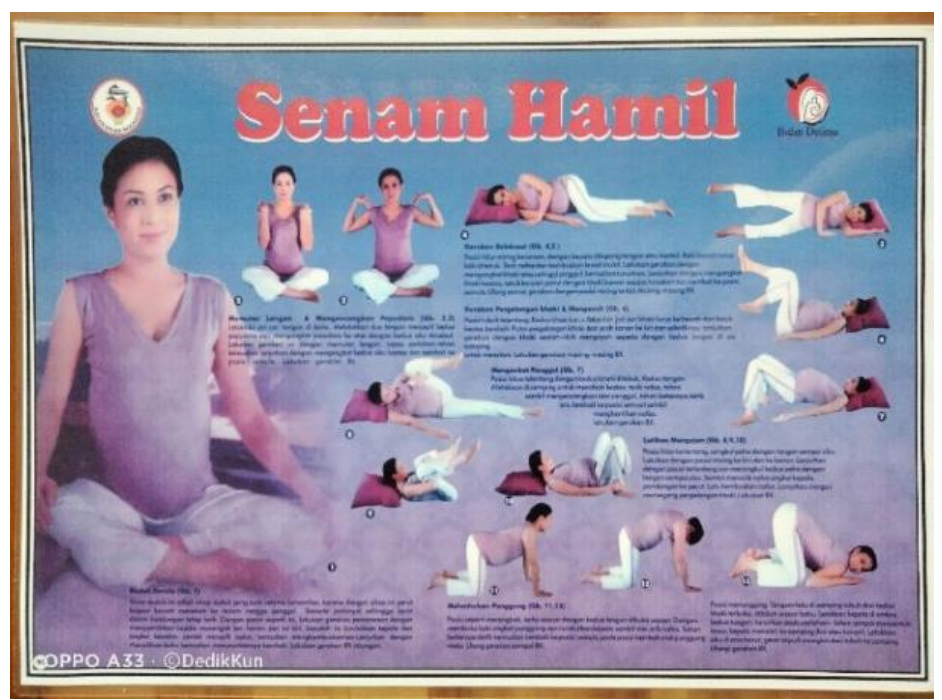

Gambar 2. Poster Senam Hamil ${ }^{4}$

\section{Asupan Nutrisi Ibu Hamil}

Pemenuhan gizi dan asupan nutrisi menjadi faktor penting dalam menjaga kesehatan dan meningkatkan imunitas tubuh. Peran dan fungsi gizi dapati memperkuat imunitas dan dapat mencegah masuknya penyakit dari luar tubuh. Kekurangan zat gizi tertentu dapat menyebabkan gangguan imunitas yang dapat membuat seseorang mudah sakit serta tidak dapat beraktifitas dengan baik (Sibuea dalam Sibuea $2021: 86$ ).

Makanan fungsional pada dasarnya adalah makanan yang mengandung gizi secara lengkap yang tidak saja memberi rasa kenyang, tetapi juga membuat tubuh sehat, aktif dan produktif. Gizi yang dimaksudkan seperti protein, karbohidrat, lemak, air, vitamin, dan mineral serta berbagai senyawa makanan dan antioksidan (Sibuea 2021:84).

lbu hamil memang termasuk kelompok yang rentan terinfeksi virus apapun, termasuk virus Corona. Kerentanan ini karena: (1) ibu hamil cenderung mengalami gangguan pada saluran pernapasan saat terinfeksi virus jenis apapun; (2) perubahan sistem imun dan kardiovaskular pada ibu hamil cenderung berpotensi untuk menderita penyakit berat jika terinfeksi virus; (3) demam dengan penyebab apapun yang lebih dari 38 derajat di usia kandungan trisemester pertama akan meningkatkan angka kelainan bawaan; (4) ibu hamil dengan penyakit penyerta, seperti gula dan darah tinggi harus lebih waspada dan hatihati. Kendati demikian ibu hamil lebih rentan, hingga saat ini belum ada bukti klinis mengenai penularan infeksi Covid-19 dari ibu ke janin di dalam kandungan, keguguran dan kematian janin ketika ibu hamil positif terinfeksi Covid-19.5

Oleh karenanya, salah satunya untuk menjaga kesehatan diri ibu hamil dan janinnya adalah dengan memerhatikan kebutuhan gizi. Di masa pandemi Covid19, kebutuhan gizi ibu hamil harus ditingkatkan lebih dari kondisi normal demi menjaga imunitas tubuh mereka (Anggraini 2021). Asupan gizi yang akan dikonsumsinya berpola empat sehat lima sempurna. Nutrisi dan gizi yang baik ketika masa kehamilan sangat membantu ibu hamil beserta janinnya tetap sehat. Pertumbuhan, perkembangan serta kesehatan yang baik bergantung pada konsumsi nutrisi yang baik serta jumlah dan

\footnotetext{
${ }^{4}$ https://cf.shopee.co.id/file/93771b7de4261e16615e1420c7964d87, diakses tanggal 11 Desember 2021.

5 https://www.kompas.com/sains/read/2020/05/10/120200723/ibu-hamil-rentan-terinfeksi-virus-corona-beginiupaya-pencegahannya?page=all, diakses tanggal 20 November 2021.
} 
kualitas nutrisi yang dikonsumsi (Bohari dan Gaffar 2021:1887). Selain nutrisi, asupan terkait dengan vitamin dan mineral juga sangat penting bagi kesehatan dan perkembangan ibu dan janinnya (Bahar dkk. 2020 dalam Bohari dan Gaffar 2021:1887-1889).

Temuan penelitian ini menunjukkan bahwa konsumsi buah-buahan dan sayursayuran adalah asupan nutrisi yang common dikonsumsi oleh ibu hamil. Wiji (25 tahun), misalnya, menyatakan bahwa selama masa kehamilannya, ia mengonsumsi banyak buah-buahan dan sayur-sayuran yang mengandung vitamin B dan C. Menurut Tri Murti (dalam Anggraini dan Anjani 2021:44), sistem imun dapat ditingkatkan oleh nutrisi yang mendukung yang berasal dari aneka makanan, sayur atau buah-buah. Sumber dari vitamin B terdapat di beberapa makanan, buah-buah maupun sayuran seperti ragi, beras, pisang, alpukat, telur, keju, ikan, daging sapi, sayuran, kacang dan lain-lain. Vitamin $B$ ini sangat diperlukan oleh tubuh dan jika kekurangan dapat menyebabkan gangguan, seperti kekurangan vitamin B6 dan B12 yang dapat menyebabkan anemia. Vitamin C diperlukan untuk meningkatkan daya tahan tubuh dan tidak dapat diproduksi oleh tubuh. Sementara itu, sumber vitamin C alami dapat diperoleh dari buah-buahan yang kaya vitamin $\mathrm{C}$, seperti strawberri, kiwi dan buah-buahan sitrus.

Wiji juga memilih untuk memasak makanannya sendiri agar lebih terjamin higienitasnya dan lebih sehat dibandingkan jika ia membeli makanan jadi. la juga sangat selektif dalam memilih jenis makanan yang dikonsumsi. Misalnya, ketimbang memasak beras putih, ia lebih memilih memasak beras merah. Bagi ibu hamil yang mengonsumsi nasi merah, maka ini berkhasiat sebagai sumber

\footnotetext{
${ }^{6}$ https://www.alodokter.com/petik-manfaat-berasmerah-untuk-ibu-hamil, diakses tanggal 27

November 2021.
}

energi, mengontrol berat badan selama hamil, meningkatkan daya tahan tubuh, mencegah anemia defisiensi zat besi, menjaga kesehatan saluran pencernaan, mengontrol kadar gula darah, dan menurunkan risiko mengalami kram kaki. ${ }^{6}$ Wiji juga mengurangi memakan makanan yang diolah dengan cara digoreng, banyak mengonsumsi air mineral, serta konsisten dalam mengonsumsi vitamin asam folat dan penambah darah yang diresepkan oleh dokter ahli kandungannya.

Ini berbeda dari Warda (24 tahun), ibu hamil yang tidak memiliki pantangan dan perhatian yang berarti dalam mengonsumsi makanan. Warda tidak begitu menyukai memakan sayur-sayuran, tapi ia mentaktisinya dengan mengonsumsi susu kehamilan yakni Prenagen dan ia juga rutin mengonsumsi buah-buahan setiap harinya. la juga mengonsumsi banyak air putih agar kebutuhan minimal air yang dikonsumsinya terpenuhi (dua liter per hari), maka ia membuat jadwal pengingat agar target tersebut terpenuhi dalam sehari.

Hal serupa juga dialami oleh Andi (24 tahun) yang selama masa kehamilan jarang mengonsumsi buah-buahan dikarenakan tidak terlalu menyukainya. Jikapun ia mengonsumsi sayuran-sayuran, itupun hanya sayur-sayuran tertentu saja. Untuk memenuhi asupan nutrisinya ia mengonsumsi yogurt sebagai penyeimbang makanannya dan secara teratur meminum susu untuk ibu hamil selama masa kehamilannya. Jika merujuk pada kandungannya, yougurt mengandung vitamin B terutama B12 dan riboflavin, tinggi protein, melancarkan pencernaan, menguatkan sistem imun, mencegah oestoperosis, dan baik untuk kesehatan jantung, sedangkan susu mengandung vitamin DB1, vitamin B12, dan vitamin D yang dapat meningkat sistem imun tubuh. 
Meskipun, Andi menganggap bahwa dengan mengonsumsi yougurt dan susu, keduanya bisa mengimbangi asupan gizi yang tidak terakomodir dari buah-buahan dan sayur-sayuran yang meskipun tidak sama persis kandungannya karena buahbuahan dan sayur-sayuran mengandung vitamin $\mathrm{B}$ dan $\mathrm{C}$.

\section{Upaya Kuratif Ibu Hamil}

Ibu hamil yang terinfeksi Covid-19 memerlukan penanganan khusus sesuai dengan tingkat beratnya gejala yang dialami. Infeksi Covid-19 dengan gejala berat bahkan memerlukan perawatan di Rumah Sakit. Bagi ibu hamil dengan gejala ringan dapat melakukan penanganannya sendiri di rumah di bawah pengawasan anggota keluarga dengan diberikan obatobatan yang sama dengan ibu yang tidak hamil, seperti obat flu atau batuk. Menurut dokter spesialis kandungan dan kebidanan, dr. Purnawan Senoaji SpOG (K) dari RS Persahabatan, penanganan ibu hamil tidak berbeda dengan pasien dengan gejala berat, mereka juga akan dibantu dengan alat bantu pernafasan. Namun, yang membuatnya berbeda, baik itu gejala ringan maupun gejala berat adalah dengan pemberian tambahan vitamin khusus dan meminum air lebih banyak untuk menjaga kondisi kehamilan. ${ }^{7}$ Bagaimana upaya yang dilakukan oleh Ibu hamil yang terinfeksi Covid-19? Ibu hamil yang terinfeksi Covid-19 menangani dirinya dengan beragam cara, yakni berolahraga, berjemur, mengonsumsi makanan yang sehat dan bergizi, dan/atau mengonsumsi vitamin penunjang kesembuhan.

Olah raga atau aktivitas fisik sebagai bagian dari pola hidup bersih dan sehat (PHBS) adalah aspek penting dan semakin penting di masa pandemi Covid19, Ghina (24 tahun), misalnya, mengalami gejala Covid-19 berupa gatal, ruam kulit

https://www.tribunnews.com/corona/2020/06/16/pe nanganan-covid-19-pada-ibu-hamil-selain-obat- dan demam serta lemas selama 10 hari di usia kandungan satu bulan. Berdasarkan hasil tes, ia positif terinfeksi Covid-19, dan sejak itu ia hanya mengonsumsi obat atau vitamin yang diresepkan oleh dokter. la tidak ingat nama obatnya, tapi menurut dokter, obat-obat tersebut diberikan sesuai dengan gejala yang dialaminya, dan obatobat tersebut mengandung zat yang dapat menaikkan imun tubuh. Sejak ia hamil, ia rutin melakukan jalan pagi (jogging) dan berjemur, namun pada saat terinfeksi Covid-19, intensitas berjemurnya lebih lama dibandingkan sebelum terinfeksi Covid-19. Meskipun sinar matahari tidak menghentikan virus Covid-19, sehingga tidak dapat mencegah infeksi, namun paparan sinar matahari dapat menjaga kondisi kesehatan pasien Covid-19, sehingga mereka memiliki kesempatan untuk pulih dari penyakit ini (Huang dkk. dalam Maulana dkk. 2021:152). Selain itu, Ghina juga memperbanyak mengonsumsi buah-buahan (seperti pisang, kurma, mangga dan alpukat) dan air mineral. Selain itu, ia menggunakan bedak tumbuk (bedda' tettu'), yang bahan-bahannya terdiri dari beras yang direndam maksimal 24 jam, kunyit yang sudah dibersihkan, daun bunga melati, semuanya di tumbuk secara bersamaan, bedda' tettu' digunakan untuk mengatasi gatal dan ruam kulitnya.

Ini berbeda dari Dwi (21 tahun) yang mengalami gejala Covid-19 berupa anosmia (hilangnya indra penciuman dan indra perasa) dan demam selama 14 hari di usia kandungan tiga bulan. Namun ia tetap beraktivitas di dalam rumah dengan mengerjakan pekerjaan-pekerjaan rumah tangga. Jika hanya berbaring saja, tubuhnya terasa lemas dan pikiran negatif mengenai kesehatan diri dan janinnya bermunculan, sehingga membuatnya stress. Oleh karenanya, ia mengimbanginya dengan beraktivitas yang

fokus-pada-pemenuhan-vitamin-dan-mineral, diakses tanggal 11 Desember 2021. 
menggerakkan tubuhnya, sehingga fikirannya teralihkan. Ketika ia merasa capek, ia berbaring hingga tertidur, sehingga tidak sempat lagi berfikir macammacam tentang kesehatan dirinya dan janin yang dikandungnya. Selain buahbuahan dan asupan bergizi yang dikonsumsinya, Dwi pun mengonsumsi multivitamin yang mengandung vitamin $\mathrm{C}$, vitamin $D$ dan zinc. Selain itu, atas saran dari keluarga ia juga mengonsumsi susu kambing yang dipercaya dapat membantu meminimalisir virus masuk ke dalam tubuh. Susu kambing sempat menjadi incaran banyak orang di saat merebaknya Covid19 karena manfaatnya yang dapat menjaga dan meningkatkan imun tubuh. ${ }^{8}$

Wiji (25 tahun), mengalami gejala Covid-19 berupa demam di hari pertama, lalu pilek selama dua hari dan anosmia selama tujuh hari di usia kandungan dua bulan, aktivitas yang ia lakukan dalam proses pemulihan dari Covid-19 ialah dengan rutin jalan pagi dan berjemur. Selain itu, ia mendisiplinkan diri dengan membuat jadwal tidur dan bangun masingmasing jam 22.00 dan jam 05.00 pagi. Namun, sebelum tidur, ia biasanya meminum air putih.

Wiji berbeda dari Indah dalam menangani Covid-19 yang menjangkitinya. Ketika Indah (24 tahun) mengalami gejala Covid-19, seperti demam, lemas dan anosmia, maka untuk meyakinkan dirinya, ia melakukan tes Covid-19 di usia kandung empat bulan. Hasil tes menunjukkan bahwa ia positif terinfeksi Covid-19. Dalam mengatasinya, ia secara rutin melakukan senam dan berjemur di rumahnya. la juga banyak mengonsumsi buah-buahan, madu, dan diberikan obat anti virus Oseltamivir serta beberapa vitamin penunjang kesembuhan yang diresepkan oleh dokter. la juga mengonsumsi suplemen vitamin C, yakni Blackmores Vitamin C 500 mg (lihat Gambar 3).

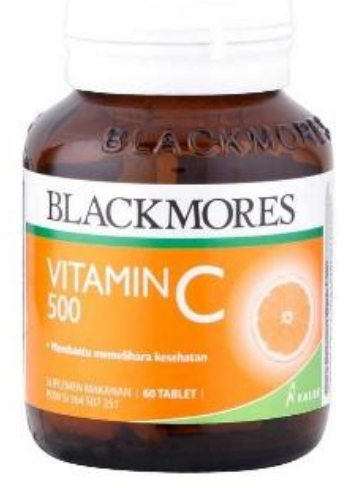

Gambar 3. Blackmores Vitamin C 500 mg ${ }^{9}$

\section{Kesimpulan dan Rekomendasi}

Ibu hamil termasuk salah satu kelompok rentan dalam kaitan dengan penularan Covid-19. Namun bagi ibu hamil, Covid-19 tidak saja memberikan dampak negatif

\footnotetext{
${ }^{8}$ https://www.rmoljabar.id/diklaim-bisa-genjotimun-tubuh-susu-kambing-saanen-jadi-buruanwarga, diakses tanggal 13 Desember 2021.

${ }^{9}$ https://www.staticsrc.com/wcsstore/Indraprastha/images/catalog/full// 96/MTA-1604768/blackmores blackmores-
}

sebagaimana imej yang terbentuk selama ini. Tapi sesungguhnya pandemi Covid-19 juga memiliki dampak positif. Dampak negatif yang dirasakan oleh ibu hamil selama pandemi Covid-19 adalah

vitamin-c-500mg-60-tablets_full02.jpg, dikases tanggal 12 Desember 2021 
timbulnya rasa ketakutan yang beragam, yang intinya ketakutan akan terinfeksi Covid-19 dan memengaruhi bayi yang dikandungnya. Namun, ibu hamil juga merasakan dampak positif selama pandemi Covid-19 karena hubungan keluarga lebih erat dan harmonis, lebih peduli terhadap kebersihan diri dan keluarga, lebih menjaga kesehatan, serta menjadi kreatif dalam memanfaatkan waktu luang.

Upaya yang dilakukan oleh ibu hamil selama pandemi Covid-19, terdiri atas upaya preventif dan upaya kuratif. Upaya preventif dilakukan dalam bentuk melakukan aktivitas fisik, seperti berolahraga, melakukan pekerjaanpekerjaan rumah tangga, mengonsumi makanan olahan sendiri, secara rutin dan teratur meminum air mineral dan susu kehamilan, memakan buah-buahan dan sayur-sayuran.

Bagi ibu hamil yang bergejala atau positif terinfeksi Covid-19, upaya kuratif yang dilakukan terutama berkaitan dengan berolah raga dan secara rutin berjemur di pagi hari, serta mengonsumsi lebih banyak makanan yang bergizi, seperti buahbuahan dan sayuran dan banyak meminum air mineral sebagai pemenuhan asupan cairan tubuh. Selain itu, ibu hamil juga mengonsumsi vitamin (seperti Ester $\mathrm{C}$ dan vitamin-vitamin lain yang diresepkan oleh dokter) untuk menjaga imunitas dan untuk mempercepat penyembuhan.

Meskipun upaya yang dilakukan oleh ibu hamil dalam kaitan dengan pencegahan dan pengobatan serupa tapi tak sama, dalam upaya preventif ibu hamil lebih banyak mengkombinasikan aktivitas fisik dan berbagai asupan yang terkait dengan upaya peningkatan daya tahan tubuh. Sedangkan dalam upaya kuratif ibu hamil membatasi durasi aktivitas fisik dan lebih rutin dalam melakukan upaya-upaya penyembuhannya. Perbedaan asupan nutrisi yang dikonsumsi pun terletak pada suplemen vitamin, jika dalam upaya preventif konsumsi suplemen tidak begitu dihiraukan dan terfokus pada makanan yang dikonsumsi, maka dalam upaya kuratif, mereka cenderung menyeimbangkan antara asupan makanan dan suplemen untuk menjaga imunitas dan mempercepat kesembuhan.

Pandemi Covid-19 memberikan dampak yang beragam terhadap ibu hamil, dalam menjaga kesehatan diri dan janin diperlukan berbagai macam upaya begitupula dalam penanganan penyakit yang menjangkiti ibu hamil, terutama Covid-19. Tapi yang terpenting dalam melakukan keduanya tidak terlepas dari kesadaran dan konsisten ibu hamil dalam menjalankannya. Ibu hamil diharapkan menyibukkan diri dengan aktivitas yang sesuai dengan kondisinya agar tidak terpaku pada kecemasan yang timbul terkait dengan pandemi Covid-19 agar kesehatan mental ibu hamil tetap terjaga.

\section{Daftar Pustaka}

Aeni, N. 2021. "Pandemi COVID-19: Dampak Kesehatan, Ekonomi, \& Sosial. Jurnal Litbang: Media Informasi Penelitian", Pengembangan dan IPTEK, 17(1):17-34, http://ejurnallitbang.patikab.go.id/index.php/jl/art icle/view/249, diakses tanggal 28 Oktober 2021.

Anggraini, N. N., dan Anjani, R. D. 2021. "Kebutuhan Gizi Ibu Hamil Pada Masa Pandemi Covid-19". Jurnal Pangan dan Gizi,11(1):42-49, https://jurnal.unimus.ac.id/index.ph p/JPDG/article/view/7491, diakses tanggal 6 November 2021.

Aritonang, J., Nugraeny, L., dan Siregar, R. N. 2020. "Peningkatan Pemahaman Kesehatan pada Ibu hamil dalam Upaya Pencegahan COVID19". Jurnal Solma, 9(2):261-269, https://journal.uhamka.ac.id/index. 
php/solma/article/view/5522,

diakses tanggal 15 Oktober 2021.

Bohari, N. H. dan Gaffar, H. R. 2021. "Pentingnya Gizi Pada Ibu Hamil Di Masa Pandemi Covid 19". JMM: Jurnal Masyarakat Mandiri, 5(4):1886-1893, http://journal.ummat.ac.id/index.ph $\mathrm{p} / \mathrm{jmm} /$ article/view/5105, diakses tanggal 12 November 2021.

Eliyun, N. dan Rahayuningsih, F.B. 2021. "Literatur Review: Upaya Pencegahan Covid-19 pada lbu Hamil”, Proceeding Seminar Keperawatan Universitas Muhammadiyah

Surakarta,https://publikasiilmiah.u ms.ac.id/bitstream/handle/11617/1 2456/11.pdf?sequence $=1$, diakses tanggal 21 November 2021.

Erlinawati, E., dan Parmin, J. 2020. "Pendidikan kesehatan pada ibu hamil dalam pencegahan penularan Covid-19 Di Puskesmas Kuok". Community Development Journal: Jurnal Pengabdian Masyarakat, 1(3):505-510, https://journal.universitaspahlawan. ac.id/index.php/cdj/article/view/124 $\underline{3}$, diakses tanggal 15 Oktober 2021.

Fauziah, N., dan Afrizal, S. 2021. "Dampak Pandemi Covid-19 dalam Keharmonisan Keluarga". SOSIETAS, 11(1):973979,

https://ejournal.upi.edu/index.php/s osietas/article/view/36092, diakses tanggal 6 Desember 2021.

Herbawani, C. K. 2021. "Dampak COVID19 pada Kesehatan Ibu Hamil: Literature Review". Jurnal Kesehatan Metro Sai Wawai, 13(2):76-85, https://ejurnal.poltekkestjk.ac.id/index.php/JKM/article/view
/2253, diakses tanggal 15 Oktober 2021.

Herlina Hinonaung, J. S., Pramardika, D. D.; Mahihody, A. J.; Wuaten, G. A., dan Manoppo, E. J. 2021. "Tinjauan Literatur COVID-19 Pada Ibu Hamil". Jurnal IImiah Kebidanan Indonesia, 11(01):44-49,

http://journals.stikim.ac.id/index.ph p/jiki/article/view/958, diakses tanggal 15 Oktober 2021.

Hinonaung, J.S.H.; Pramardika, D.D.; Mahihody, A.J.; Wuaten, G.A.; dan Manoppo, E.J. 2021. "Tinjauan Literatur Covid-19 pada Ibu Hamil", Jurnal IImiah Kebidanan Indonesia, 11(1):44-49, https://journals.stikim.ac.id/index.p hp/jiki/article/view/958/566, diakses tanggal 24 November 2021.

Indah, S., dan Rohmania, A. Z. 2017. "Pengaruh Konsumsi Buah Pisang Raja, Minum Air Mineral Dan JalanJalan Pagi Terhadap Kejadian Konstipasi Pada Ibu Hamil Trimester III Di BPS Sunarsih Yudhawati". Biomed Science, 5(1):13-17, https://jurnal.unitri.ac.id/index.php/ biomed/article/view/848, diakses tanggal 27 November 2021.

Indarwati, I., Kurniawati, A. A., Wahyuni, E. S., dan Maryatun, M. 2019. "Kajian Aktivitas Fisik Ibu Hamil Dalam Menjaga Kehamilannya Di Wilayah Kerja Puskesmas KarangTengah Kabupaten Wonogiri". Jurnal Kebidanan Indonesia, 10(2):8-18, https://jurnal.stikesmus.ac.id/index. php/JKebln/article/view/275, diakses tanggal 5 November 2021.

Kostania, G., Damayanti, M., Ningtyas Prabasari, S., Andariya Ningsih, D., Fitriyani, F., Raidanti, D., ... \& Maolinda, W. 2021. "Adaptasi Kebiasan Baru Dalam Kebidanan di 
Era Pandemi Covid-19 Edisi 2". Malang: CV Penulis Cerdas Indonesia.

http://repository.stikesrspadgs.ac id/id/eprint/465, diakses tanggal 12 Desember 2021.

Maulana, M. I., Rahman, M. F. A., Claudia, C., Helfiana, N., \& Masnina, R. 2021, October. "Meningkatkan Imunitas di Era Covid-19 melalui Kebiasaan Mencuci Tangan dan Berjemur Matahari Pagi". In Prosiding Seminar Nasional Pengabdian Kepada Masyarakat: Peduli Masyarakat 1(1):151-158, http://jurnal.globalhealthsciencegro up.com/index.php/PSNPKM/article/ view/643, diakses tanggal 27 November 2021.

Nur Damayanti, F., dan Riafisari, A. A. 2020. "Literatur Review: Komplikasi Kehamilan Pada Ibu Hamil yang Terinfeksi Covid-19". In Prosiding Seminar Nasional Unimus, 3:703710,

https://prosiding.unimus.ac.id/index .php/semnas/article/viewFile/733/7 $\underline{42}$, diakses tanggal 15 Oktober 2021.

Prananda, A. R., dan Ikhsani, A. 2021. "Infeksi Covid-19 (SarsCov-2) Pada Kehamilan". Jurnal Kesehatan Tambusai, 2(2):1-9, https://journal.universitaspahla wan.ac.id/index.php/jkt/article/ view/1734, diakses tanggal 15 Oktober 2021.

Rohmah, M.K. dan Nurdianto, A.R. 2020. "Corona Virus Disease 2019 (Covid-19) pada Wanita Hamil dan Bayi: Sebuah Tinjauan Literatur", Medica Hospitalia, Agustus, 7(1A):329-336, http://medicahospitalia.rskariadi.co. id/medicahospitalia/index.php/mh/a rticle/view/476/328, diakses tanggal 18 Oktober 2021.

Rustikayanti, R. N., Anam, A. K., dan Hernawati, Y. 2020. "Korelasi Aktivitas Fisik Dengan Kualitas Tidur Ibu Hamil: Studi CrossSectional". Jurnal Perawat Indonesia, 4(2):344-350, http://journal.ppnijateng.org/index.p hp/jpi/article/view/313, diakses tanggal 5 November 2021.

Sibuea, P. 2021. "Kajian Manfaat Makanan Fungsional di Saat Pandemi Covid19". Jurnal Riset Teknologi Pangan Dan Hasil Pertania (RETIPA), 2(1):83-92, http://ejournal.ust.ac.id/index.php/r etipa/article/view/1483, diakses tanggal 5 November 2021.

Siregar, R. N., Aritonang, J., dan Anita, S. 2020. "Pemahaman Ibu Hamil Tentang Upaya Pencegahan Infeksi COVID-19 Selama Kehamilan". Journal Of Healthcare Technology And Medicine, 6(2):798-805, http://jurnal.uui.ac.id/index.ph $\mathrm{p} / \mathrm{JHTM} /$ article/view/986 diakses tanggal 15 Oktober 2021.

Suka, I. D. M. 2021. "Strategi Penguatan Fungsi Keluarga Pada Era Pandemi Covid-19". Social: Jurnal Inovasi Pendidikan IPS, 1(1):36-43. https://www.jurnalp4i.com/index.ph $\mathrm{p} /$ social/article/view/254, diakses tanggal 6 Desember 2021. 